\title{
Biliary atresia: the Brazilian experience
}

\author{
ELISA DE CARVALHO ${ }^{1}$, JORGE LUIZ DOS SANTOS ${ }^{2}$, THEMIS REVERBEL DA SILVEIRA², \\ CARLOS OSCAR KIELING ${ }^{3}$, LUCIANA RODRIGUES SILVA4, GILDA PORTA 5 , \\ IRENE KAZUE MIURA ${ }^{5}$, ADRIANA MARIA ALVES DE TOMMASO ${ }^{6}$, \\ MARIA ÂNGELA BELLOMO BRANDÃ ${ }^{6}$, ALEXANDRE RODRIGUES FERREIRA ${ }^{7}$, \\ JOSÉ ROBERTO DE DEUS MACÊDO ${ }^{8}$, JOSÉ TENÓRIO DE ALMEIDA NETO ${ }^{8}$. \\ GRUPO DE ESTUDOS EM HEPATOLOGIA PEDIÁTRICA DO BRASIL
}

1. PhD. Hospital de Base do Distrito Federal (HBDF), Brasília, DF, Brazil.

2. PhD. Hospital de Clínicas de Porto Alegre (HCPA), Universidade Federal do Rio Grande do Sul (UFRGS), Porto Alegre, RS, Brazil.

3. MD. HCPA, UFRGS, Porto Alegre, RS, Brazil.

4. PhD. Universidade Federal da Bahia (UFBA), Salvador, BA, Brazil.

5. PhD. Hospital Sírio-Libanês, São Paulo, SP, Brazil. Hospital A. C. Camargo, São Paulo, SP, Brazil.

6. PhD. Universidade Estadual de Campinas (UNICAMP), Campinas, SP, Brazil.

7. PhD. Universidade Federal de Minas Gerais (UFMG), Belo Horizonte, MG, Brazil.

8. MD. HBDF, Brasília, DF, Brazil..

\begin{abstract}
Objective: To evaluate epidemiological, clinical and prognostic characteristics of children with biliary atresia. Methods: Data regarding portoenterostomy, liver transplantation (LTx), age at last follow-up and survival were collected from the records of patients followed up in six Brazilian centers (1982-2008) and compared regarding decades of surgery. Results: Of 513 patients, $76.4 \%$ underwent portoenterostomy [age: 60-94.7 (82.6 \pm 32.8 ) days] and $46.6 \%$ underwent LTx. In $69 \%$ of cases, LTx followed portoenterostomy, whereas in $31 \%$ of cases LTx was performed as the primary surgery. Patients from the Northeast region underwent portoenterostomy later than infants from Southern $(p=0.008)$ and Southeastern $(p=0.0012)$ Brazil, although even in the latter two regions age at portoenterostomy was higher than desirable. Over the decades, LTx was increasingly performed. Overall survival was $67.6 \%$. Survival increased over the decades $(1980 \mathrm{~s}$ vs. $1990 \mathrm{~s}, \mathrm{p}=0.002$; $1980 \mathrm{~s} v s$ 2000s, $\mathrm{p}<0.001 ; 1990 \mathrm{~s}$ vs. 2000s, $\mathrm{p}<0.001)$. The 4 -year post-portoenterostomy survival, with or without LTx, was $73.4 \%$, inversely correlated with age at portoenterostomy $(80,77.7$ and $60.5 \%$ for $\leq 60,61$ 90 and $>90$ days, respectively). Higher survival rates were observed among transplanted patients $(88.3 \%)$. The 4-year native liver survival was $36.8 \%$, inversely correlated with age at portoenterostomy $(54,33.3$ and $26.6 \%$ for $\leq 60,61-90$ and $>90$ days, respectively). Conclusions: This multicenter study showed that late referral for biliary atresia is still a problem in Brazil, affecting patient survival. Strategies to enhance earlier referral are currently being developed aiming to decrease the need for liver transplantation in the first years of life. (Key words: Biliary atresia, portoenterostomy, hepatic, surgery, diagnosis, differential, prognosis). J Pediatr (Rio J) 2010; 86 (6): 473-479.
\end{abstract}

\section{ESTE TRABAJO LO PUEDE ENCONTRAR EN EXTENSO EN WWW.SciELO.ORG}

No conflicts of interest declared concerning the publication of this article

Correspondencia a:

Elisa de Carvalho

E-mail: elisacarvalho@terra.com.br 